\title{
Optimization of Solvent Extraction of the Leaves of Premna serratifolia and Quantitation of Premnaodoroside A by Validated TLC-densitometric Method
}

\author{
Khin Su Yee ${ }^{1,2}$, Tasamaporn Sukwattanasinit', Uthai Sotanaphun ${ }^{1}$, Penpun Wetwitayaklung ${ }^{1}$, Bunyapa \\ Wangwattana ${ }^{1}$, Worrakanya Narakornwit ${ }^{1, *}$
}

\section{Khin Su Yee ${ }^{1,2}$, Tasamaporn \\ Sukwattanasinit ${ }^{1}$, Uthai \\ Sotanaphun', Penpun \\ Wetwitayaklung', Bunyapa \\ Wangwattana ${ }^{1}$, Worrakanya \\ Narakornwit ${ }^{1, *}$}

'Department of Pharmacognosy, Faculty of Pharmacy, Silpakorn University, Nakhon Pathom, THAILAND.

${ }^{2}$ Department of Pharmacognosy, University of Pharmacy, Mandalay, MYANMAR.

\section{Correspondence}

\section{Worrakanya Narakornwit}

Department of Pharmacognosy, Faculty of Pharmacy, Silpakorn University, Nakhon Pathom, THAILAND.

E-mail: SIRINAMARATTANA_A@su.ac.th History

- Submission Date: 27-09-2021;

- Review completed: 10-10-2021;

- Accepted Date: 14-10-2021.

DOI : 10.5530/pj.2021.13.213

Article Available online http://www.phcogj.com/v13/i6

\section{Copyright}

(C) 2021 Phcogj.Com. This is an open access article distributed under the terms of the Creative Commons Attribution 4.0 International license.

\begin{abstract}
Introduction: The leaves of Premna serratifolia have been widely used in traditional medicine. Its major constituents were iridoid glycosides and phenolic compounds. Antioxidation was one of its reported bioactivities. The aim of this study was to optimize the ethanol concentration used to obtain high quality extracts. Methods: Three sources of leaf samples were separately extracted by $0,20,40,60,80$ and $100 \%$ ethanol. Their content of premnaodoroside A, the major glycoside, was determined by a TLCdensitometric method developed in this study. The content of total phenolic compounds and antioxidants were also determined by Folin-Ciocalteu and DPPH scavenging methods, respectively. Results: The developed TLC-densitometric method showed a good linearity $\left(R^{2}>0.99\right)$ in the range of $0.11-0.872$ $\mu \mathrm{g} / \mathrm{spot}$. Its limit of detection and limit of quantitation were 0.13 and $0.04 \mu \mathrm{g} / \mathrm{spot}$, respectively. The method had satisfactory specificity, precision and accuracy. The analysis results of all extracts showed that the $100 \%$ ethanolic extracts exhibited the highest contents of premnaodoroside A (3.23-5.25\%), total phenolic compounds $(7.56-8.24 \%$ GAE) and antioxidants $(4.92-6.66 \%$ AAE), but its extractive yields (13.57-19.57\%) were the lowest. Yields of the $40 \%$ and the $80 \%$ ethanolic extracts were the highest in two samples $(36.37-45.96 \%)$ and one sample $(47.53 \%)$, respectively. Considering of the extractive ability, the $80 \%$ ethanol could extract the highest amounts of all investigated compounds from plant material. Conclusion: The $100 \%$ ethanolic extract possessed the highest contents of the interesting compounds, but the $80 \%$ ethanolic extract had a higher extractive yield. Their benefits and drawbacks must be considered, depending on further application.

Key words: Antioxidation, Extraction optimization, premnaodoroside A, Premna serratifolia, TLCdensitometry, Total phenolic.
\end{abstract}

\section{INTRODUCTION}

Premna serratifolia L. (synonym: P. integrifolia L.) belongs to the family Lamiaceae. It is widely distributed in tropical and subtropical Asia, Australia and Africa. ${ }^{1}$ It has been used in traditional medicine for cardiotonic, anticoagulant, carminative, hepatoprotective, antitumor $^{2}$, anti-diabetics and anti-inflammatory. ${ }^{3}$ In Vietnamese traditional medicine, the leaves of this plant are used to alleviate indigestion, dysuria and dysentery. ${ }^{4}$ In Peninsular Malaysia and Indonesia, young leaves are boiled and consumed as a vegetable. ${ }^{1}$ Previous publications reported that the leaves of $P$. serratifolia possessed antioxidant activity and its phytochemicals were iridoid glycoside, flavonoids, alkaloids, terpenoids, tannins and steroids. ${ }^{5,6}$ A number of iridoid glycosides have been isolated from the leaves of this plant. ${ }^{7}$ Iridoid glycosides have numerous biological activities and plays an important position in the field of natural product chemistry and biology. ${ }^{7} \mathrm{HPLC} / \mathrm{MS}$, HPLCDAD-ESI/MS, and HPTLC have been used for the quantitation of some iridoid glycosides reported from Veronica sp. ${ }^{8}$ Globularia punctate ${ }^{9}$ and, Gmelina aroborea. ${ }^{10}$ In practice, the leaves of this plant were easily fermented, turned to black color, and caused changes in its chemical constituents. ${ }^{11}$ Therefore, drying the leaves immediately after collection was important to keep their quality for long-term use. Infusion and decoction were the traditional preparation methods..$^{12}$ In the production of modern herbal medicinal products, herbal extract is raw material commonly used because unwanted materials are eliminated, its chemical constituents are concentrated and it can be further processed into several herbal dosage forms. ${ }^{13}$ This study aimed to gain some basic information on the effect of solvent on the extraction of this plant. Various percentages of ethanol were studied. The quality of the extraction was examined based on the extractive yield, and the contents of the interesting analytical markers, including a major iridoid glycoside, total phenolic compounds and antioxidative activity of the resulting extracts. The major iridoid glycoside was isolated from the leaves of this plant and quantified by a reliably TLC-densitometric method developed in this study. Appropriate percentages of ethanolic solvent were optimized to obtain good quality of herbal extracts in both quantity and quality aspects.

\section{MATERIALS AND METHODS}

\section{Plant material}

The leaves of $P$. serratifolia L. were collected from three sources, (1) Aungmyethazan, (2) Chanayethazan and (3) Pathingyi, Mandalay, Myanmar, in December, 2018. Identification of 
the plant was done by comparing with authentic references. ${ }^{14,15}$ The voucher specimen is deposited in the herbarium of the Department of Pharmacognosy, Silpakorn University, Thailand. The leaves were airdried, ground into powder and passed through a $0.85 \mathrm{~mm}$ sieve.

\section{Isolation of Premnaodoroside A}

The air-dried ground leaves (480 g) were sequentially exhaustively extracted with hexane, dichloromethane and methanol by Soxhlet extraction. The extracts were evaporated under reduced pressure to give crude hexane, dichloromethane and methanol extracts (13.81, 8.16 and $23.49 \mathrm{~g}$, respectively). Part of methanolic extract (18 g) was separated into 18 fractions by a gel column chromatography using Sephadex LH-20 (Sigma; MO, USA) eluted with methanol. The combined fractions no.4-5 $(3.11 \mathrm{~g})$ was further purified by a silica gel $60(0.040$ $0.063 \mathrm{~mm}$, Darmstadt, Germany) column chromatography eluted with dichloromethane : methanol : water $(1: 4: 0.1)$ to obtain a pure compound $(54.1 \mathrm{mg})$. Its structure was identified as premnaodoroside A (Figure 1) by comparing its spectroscopic data $\left({ }^{1} \mathrm{H}-\mathrm{NMR},{ }^{13} \mathrm{C}-\mathrm{NMR}\right)$ with those previously reported. ${ }^{7,16}$ Its purity as $87.2 \%$ was assessed by the TLC densitometric method. This compound was used as a standard marker for this study.

Premnaodoroside A. Yellowish white amorphous powder, $\lambda^{\mathrm{MeOH}} \max$ $\mathrm{nm}(\log \varepsilon): 225$ (4.06); ESIMS $m / z 888.5$ [M-H] $^{-}\left(\mathrm{C}_{42} \mathrm{H}_{66} \mathrm{O}_{20}, \mathrm{M}=890\right)$; ${ }^{1} \mathrm{H}-\mathrm{NMR} \delta \mathrm{ppm}, 300 \mathrm{~Hz}(\mathrm{MeOD}): 5.45(2 \mathrm{H}, d, J=4.5 \mathrm{~Hz}, \mathrm{H}-1 \mathrm{a}, \mathrm{H}-1 \mathrm{~b})$, 7.39, $(\mathrm{H}, s, \mathrm{H}-3 \mathrm{a}), 7.41(\mathrm{H}, s, \mathrm{H}-3 \mathrm{~b}), 3.2 \sim 3.3$ (proton overlapped by the solvent, $\mathrm{H}-5), 1.65(\mathrm{H}, m, \mathrm{H}-6), 1.75(5 \mathrm{H}, m, \mathrm{H}-6), 1.78,(\mathrm{H}, m$, $\mathrm{H}-7), 2.22(2 \mathrm{H}, d d, J=4.2,9.3 \mathrm{~Hz}, \mathrm{H}-9), 1.32(3 \mathrm{H}, s, \mathrm{H}-10), 4.17$ ( $t, J=5.9$ $\left.\mathrm{Hz} \mathrm{H}-1^{\prime \prime}\right), 1.59$ ( $\left.m, \mathrm{H}-2 ", 1.74, m, \mathrm{H}-2^{\prime \prime}\right), 1.4-1.5$ ( $\left.m, \mathrm{H}-3 "\right), 1.19 \sim 1.37$ (proton overlapped by the water, H-4", H-5", H-6"), 1.82 ( $\left.m, \mathrm{H}-7^{\prime \prime}\right)$, $3.92\left(\mathrm{H}, m, \mathrm{H}-8^{\prime \prime}\right), 0.91\left(3 \mathrm{H}, d, J=6.3 \mathrm{~Hz}, \mathrm{H}-9^{\prime \prime}\right), 0.96(3 \mathrm{H}, d, J=7.2 \mathrm{~Hz}$, $\left.\mathrm{H}-10^{\prime \prime}\right), 4.68\left(\mathrm{H}, d, J=7.8 \mathrm{~Hz}, \mathrm{H}-1^{\prime}\right), 3.2 \sim 3.3$ (proton overlapped by the solvent, H-2', H-3', H-4'), $3.37\left(2 \mathrm{H}, t, \mathrm{H}-5^{\prime}\right), 3.90(2 \mathrm{H}, d d, J=11.9$, $6.3 \mathrm{~Hz}, \mathrm{H}-6$ ); ${ }^{13} \mathrm{C}-\mathrm{NMR} \delta \mathrm{ppm}, 300 \mathrm{~Hz}$ (MeOD): 95.61, 95.61 (C-1), 152.07, 152.07 (C-3), 113.71, 113.75 (C-4), 32.23, 32.23 (C-5), 31.09, 31.06 (C-6), 40.80, $40.84(\mathrm{C}-7), 80.69,80.72(\mathrm{C}-8), 52.42,52.42(\mathrm{C}-9)$, 24.82, 24.82 (C-10), 169.19, 169.25 (C-11), 63.65 (C-1"), 36.91 (C-2"), $31.15\left(\mathrm{C}-3^{\prime \prime}\right), 38.24\left(\mathrm{C}-4^{\prime \prime}\right), 25.34\left(\mathrm{C}-5^{\prime \prime}\right), 34.85\left(\mathrm{C}-6^{\prime \prime}\right), 34.06\left(\mathrm{C}-7^{\prime \prime}\right)$, 70.09 (C-8"), 20.03 (C-9"), 17.56 (C-10"), 99.86, 99.98 (C-1'a, 1'b), 74.76, 74.89 (C-2'a, 2'b), 78.40, 78.53 (C-3'a, 3'b), 71.75, 71.87 (C-4'a, $\left.4^{\prime} \mathrm{b}\right), 78.02,78.13$ (C-5'a, 5'b), 62.98, 63.1(C-6'a, 6'b).

\section{Sample preparation}

The dried leaf powder ( $30 \mathrm{~g}$ ) was separately extracted with $600 \mathrm{ml}$ of 0,20 , $40,60,80$ and $100 \%$ ethanol by heating at $100^{\circ} \mathrm{C}$ for $2 \mathrm{hr}$. The extracts were evaporated to dryness and \% yield calculated. Each extract was dissolved in ethanol to obtain an appropriate concentration for the analysis.

\section{TLC condition}

TLC analysis was performed on a silica gel $60 \mathrm{~F}_{254}(0.040-0.063 \mathrm{~mm}$, Merck, Germany) aluminium sheet $20 \times 10 \mathrm{~cm}$. Sample and standard solutions $(2 \mu \mathrm{L})$ were spotted and pre-concentrated by developing in $100 \%$ methanol for a distance of $4 \mathrm{~mm}$. After air-drying, it was developed to a distance of $8 \mathrm{~cm}$ with ethyl acetate : methanol : ammonium hydroxide solution $(50: 35: 15)$ solvent system in a TLC tank previously saturated for 180 minutes. The plate was air-dried and dipped in vanillin/sulfuric reagent ( $5 \mathrm{~g}$ vanillin in $475 \mathrm{ml}$ of ethanol and $25 \mathrm{ml}$ of concentrated sulphuric acid, freshly prepared) in a dipping tank for 1 minute. It was dried and heated at $110^{\circ} \mathrm{C}$ for 3 minutes and obtain a clear result.

\section{TLC-densitometric method}

The developed TLC chromatogram was scanned at 15 minutes after derivatization by using CAMAG TLC Scanner II operated by Camag CATS 1.4.9.210184 software in the reflectance-absorbance mode at the wavelength of $520 \mathrm{~nm}$. The slit dimension of $12.00 \times 0.90 \mathrm{~mm}$, macro, and $20 \mathrm{~mm} / \mathrm{s}$ scanning speed were employed for densitometric parameters.

\section{Calibration curve}

The standard stock solution $(4.36 \mathrm{mg} / \mathrm{mL})$ of premnaodoroside A was prepared in ethanol. Working solution $(0.055-0.436 \mathrm{mg} / \mathrm{mL})$ was prepared by appropriate dilution of the standard solution with ethanol. Two $\mu \mathrm{L}$ of each solution were applied on a TLC plate. The chromatogram was developed and the plate was scanned and analyzed. The calibration curve was constructed between peak areas and amounts of the compound (0.11-0.872 $\mu \mathrm{g} / \mathrm{spot}$ ) by least square linear regression.

\section{Method validation}

The quantitative densitometric method was validated for linearity, precision, accuracy, recovery, limit of detection (LOD), limit of quantitation (LOQ) and robustness according to the International Conference on Harmonization (ICH, 2005) guidelines. ${ }^{17}$

\section{Determination of total phenolic content}

Folin-Ciocalteu method was used to determine the total phenolic content in the extract by modifying the method of Timotius, et al. $(2018)^{11}$. Sample solution $(200 \mu \mathrm{g} / \mathrm{mL}$ in ethanol $) 0.5 \mathrm{~mL}$ was mixed with $2.5 \mathrm{~mL}$ of $10 \%$ Folin-Ciocalteu reagent (Fluka; Buchs, SG, Schweiz) and allowed to stand for 5 minutes. Then, $2 \mathrm{~mL}$ of $5 \%$ sodium carbonate was added, mixed and kept for 180 minutes. The absorbance was measured at $765 \mathrm{~nm}$ (Hitachi U-2000 spectrophotometer, Tokyo, Japan). A calibration curve of gallic acid used as reference was constructed between the final concentration and absorbance value. The total phenolic content of the extract was expressed as gallic acid equivalent (\%GAE). The experiment was done in triplicate.

\section{Determination antioxidant activity}

Antioxidant activity of the extracts was determined by DPPH radical scavenging assay with some modification (Timotius, et al. 2018) ${ }^{11}$. Two $\mathrm{mL}$ of sample solution $(200 \mu \mathrm{g} / \mathrm{ml}$ in ethanol) were mixed with $2 \mathrm{~mL}$ of DPPH solution $(75 \mu \mathrm{g} / \mathrm{ml}$ in ethanol). The reaction was kept for 60 minutes in a dark place. The absorbance was measured at 517 nm (Hitachi U-2000 spectrophotometer, Tokyo, Japan). Ascorbic acid $(2-16 \mu \mathrm{g} / \mathrm{mL}$ in ethanol) was used as a positive reference to construct a calibration curve between the final concentration and \%activity. Antioxidant activity of the sample was calculated as ascorbic acid equivalent (\%AAE). The experiment was done in triplicate.

\section{Statistical analysis}

All data were demonstrated as mean \pm standard deviation, and analysis of variance was performed using one-way ANOVA of the Excel. A statistically significant p-value was estimated to be less than 0.05 .

\section{RESULTS}

\section{Yield of the extracts}

The extracts of $P$. serratifolia leaves were prepared by using $0,20,40$, 60,80 and $100 \%$ ethanol as solvent. The samples from three different locations were used to confirm the result. Yields of the extracts are shown in Table 1 . The $100 \%$ ethanolic extracts of all samples gave the lowest $\%$ yield, whereas the highest $\%$ yield was variation among samples. The $80 \%$ ethanolic extract gave the highest yield for sample 1 , but it was the $40 \%$ ethanolic extracts for the other two samples.

\section{Development of TLC-densitometric method}

A TLC densitometric method was developed to quantify the content of premnaodoroside A in the ethanolic extracts. Premnaodoroside A was the main iridoid glycoside, and it was purified in our laboratory for 
using as a standard. After determining various mobile phase systems, the system of ethyl acetate : methanol : ammonium hydroxide solution ( $50: 35: 15)$ was employed. Visualization of the compound was done by derivatization with vanillin/sulphuric acid reagent. Peak purity of premnaodoroside $\mathrm{A}$ in the extracts was determined by comparing the spectra in the range of 450-700 $\mathrm{nm}$ at peak start, peak apex and peak end positions of the standard band. Their correlations were more than 0.99 . There was no interfering peak observed in densitograms of the standard and the extracts which indicated specificity by the result (Figure 2 ). The calibration curve $(\mathrm{Y}=5317.1 \mathrm{X}+249.18)$ was established by plotting between the peak areas and the concentrations of the standard, which demonstrated a good linearity $\left(\mathrm{R}^{2}>0.99\right)$ within the concentration range of $0.11-0.872 \mu \mathrm{g} / \mathrm{spot}$. LOD and LOQ were calculated from the intercept and the SD of the slope of the calibration curve as 0.13 and 0.04 $\mu \mathrm{g} / \mathrm{spot}$, respectively. The repeatability (intra-day) and intermediate precision (inter-day) were performed by determining the amount of premnaodoroside A at three concentrations of $0.11,0.44$ and $0.87 \mu \mathrm{g} /$ spot in 5 replications. All results of \%RSD were lower than 3\%. The accuracy of the method was in the range of $99-100 \%$ (Table 2). The average recovery of three concentrations of spiked standard compound $(0.22,0.35$, and $0.44 \mu \mathrm{g} / \mathrm{spot})$ was $97.08-101.16 \%$, indicating the good accuracy of the method (Table 3). Robustness was performed at five concentrations (0.11-0.87 $\mu \mathrm{g} / \mathrm{spot})$. The results indicated that the peak area decreased with time after derivatization from 15 to 25 minutes (Table 4).

\section{Quantitative determination of premnaodoroside A}

Content of premnaodoroside $\mathrm{A}$ in the ethanolic extracts was determined by the developed TLC-densitometric method. The results of the samples from the three sources were in the same manner as shown in Figure 3. Different percentages of ethanol gave a significant difference in the concentrations of this compound in the resulting extracts $(\mathrm{p}<$ $0.05)$. Its contents increased with the percentage of ethanol. $0 \%$ Ethanol extract had the lowest concentration (0.53-0.89\%), and the highest concentration was detected in $100 \%$ ethanol extract (3.23-5.25\%).

\section{Total phenolic contents and antioxidant activity}

Total phenolic content (\%GAE) and antioxidant activity (\%AAE) of the extracts were determined by DPPH assay and Folin-Cioalteu method, respectively. The results of all samples were in the same manner (Figures 4 and 5). Different percentage of ethanol gave a significantly different result $(\mathrm{p}<0.05) . \% \mathrm{GAE}$ and \%AAE increased with the percentages of ethanol. $100 \%$ ethanol extracts exhibited the highest \%GAE (7.56-8.24\%) and \%AAE (4.92-6.66\%).

Table 1: Yield of the ethanolic extracts.

\begin{tabular}{|cccc|}
\hline $\begin{array}{c}\text { Solvent } \\
\text { (\%Ethanol) }\end{array}$ & Sample 1 & Sield & Sample 2 \\
\cline { 2 - 4 } & 38.16 & 38.96 & 31.57 \\
20 & 40.53 & 44.89 & 34.96 \\
40 & 41.74 & 45.96 & 36.37 \\
60 & 42.35 & 41.65 & 34.16 \\
80 & 47.53 & 38.54 & 27.74 \\
100 & 18.37 & 19.57 & 13.57 \\
\hline
\end{tabular}

Table 2: Precision and accuracy of the TLC-densitometric method.

\begin{tabular}{|c|c|c|c|c|c|}
\hline Loading ( $\mu \mathrm{g} / \mathrm{spot}$ ) & Day & $\begin{array}{l}\text { Amount detected } \\
(\mu \mathrm{g} / \mathrm{spot})\end{array}$ & Repeatability $(n=5)$ & $\begin{array}{l}\text { Intermediate } \\
\text { precision }\end{array}$ & \%Accuracy \\
\hline \multirow{3}{*}{0.11} & 1 & $0.11 \pm 0.0008$ & 0.77 & \multirow{3}{*}{0.09} & 100.07 \\
\hline & 2 & $0.11 \pm 0.0001$ & 0.13 & & 99.99 \\
\hline & 3 & $0.11 \pm 0.0005$ & 0.47 & & 99.86 \\
\hline \multirow{3}{*}{0.44} & 1 & $0.44 \pm 0.002$ & 0.04 & \multirow{3}{*}{0.28} & 100.04 \\
\hline & 2 & $0.44 \pm 0.002$ & 0.41 & & 99.72 \\
\hline & 3 & $0.44 \pm 0.009$ & 2.16 & & 100.27 \\
\hline \multirow{3}{*}{0.87} & 1 & $0.87 \pm 0.003$ & 0.41 & \multirow{3}{*}{0.11} & 99.92 \\
\hline & 2 & $0.87 \pm 0.007$ & 0.83 & & 100.18 \\
\hline & 3 & $0.87 \pm 0.009$ & 1.11 & & 100.04 \\
\hline
\end{tabular}

Table 3: Recovery data of the TLC-densitometric method.

\begin{tabular}{cccc}
\hline Amount added $(\mu \mathrm{g} / \mathrm{spot})$ & Amount detected $(\mu \mathrm{g})$ & Recovery $(\%)$ & Average recovery $(\%)$ \\
\hline 0.22 & $0.22 \pm 0.01$ & $101.16 \pm 5.45$ & \\
0.35 & $0.34 \pm 0.01$ & $97.32 \pm 3.78$ & $98.52 \pm 2.29$ \\
0.44 & $0.43 \pm 0.01$ & $97.08 \pm 3.16$ & \\
\hline
\end{tabular}

Table 4: Robustness of the method (the peak areas after derivatization).

\begin{tabular}{|c|c|c|c|c|c|c|}
\hline \multirow{2}{*}{$\begin{array}{c}\text { Standard } \\
\text { concentration } \\
(\mu \mathrm{g} / \mathrm{spot})\end{array}$} & \multicolumn{3}{|c|}{ Time after derivatization (min) } & \multirow[b]{2}{*}{ Mean } & \multirow[b]{2}{*}{ SD } & \multirow[b]{2}{*}{$\%$ RSD } \\
\hline & 15 & 20 & 25 & & & \\
\hline 0.87 & 3447.9 & 3278.9 & 3117.8 & 3281.5 & 165.07 & 5.03 \\
\hline 0.65 & 3523.6 & 3365.4 & 3247.4 & 3378.8 & 138.59 & 4.10 \\
\hline 0.44 & 1822.3 & 1822.3 & 1676.5 & 1747.5 & 72.97 & 4.18 \\
\hline 0.22 & 1035.8 & 1035.8 & 953.3 & 992.4 & 41.42 & 4.17 \\
\hline 0.11 & 473.7 & 473.7 & 455.3 & 462.2 & 10.05 & 2.17 \\
\hline
\end{tabular}




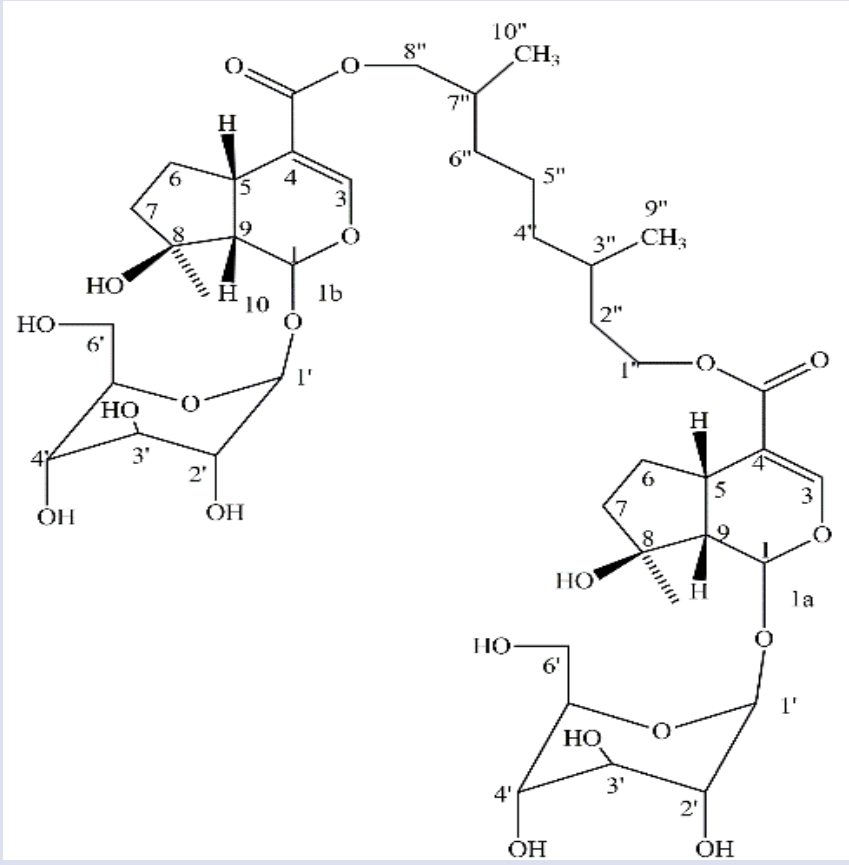

Figure 1: Structure of premnaodoroside A.

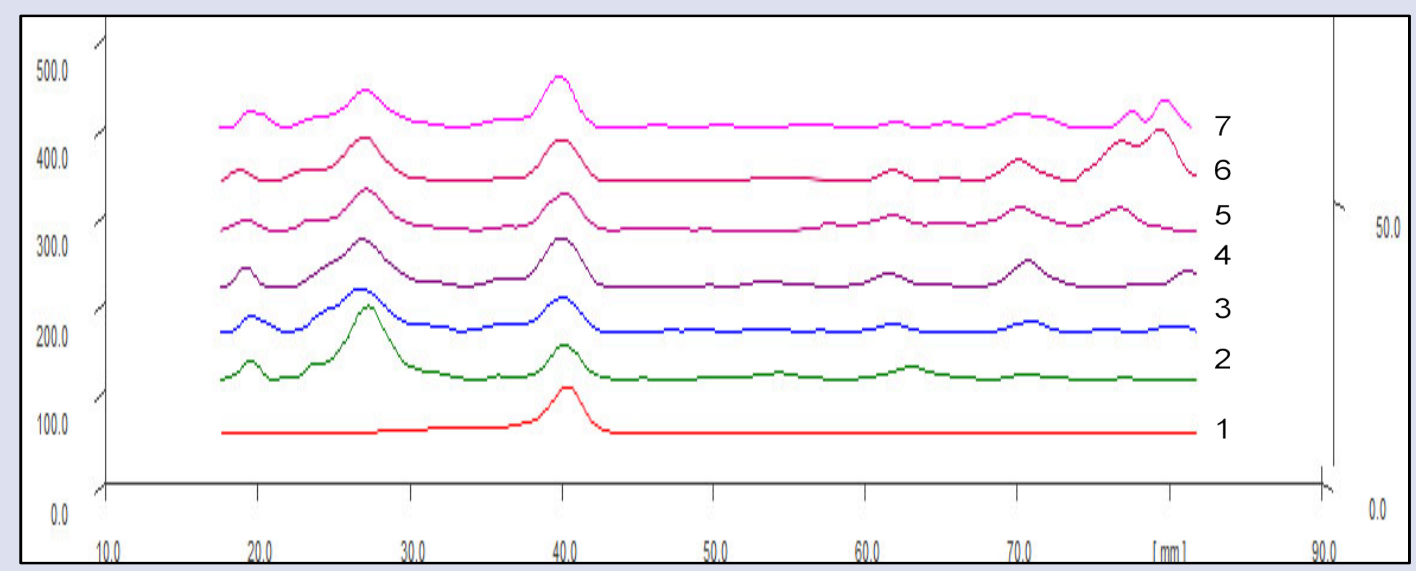

Figure 2: Densitograms of standard premnaodoroside $A$ and the ethanolic extracts. $1=$ standard $(0.34 \mu \mathrm{g} / \mathrm{spot}), 2=0 \%$ ethanolic extract $(84.68 \mu \mathrm{g} / \mathrm{spot}), 3=20 \%$ ethanolic extract $(30.52 \mu \mathrm{g} / \mathrm{spot}), 4=40 \%$ ethanolic extract $(30.32 \mu \mathrm{g} / \mathrm{spot}), 5=60 \%$ ethanolic extract $(18.84 \mu \mathrm{g} / \mathrm{spot}), 6=80 \%$ ethanolic extract $(19.06 \mu \mathrm{g} / \mathrm{spot}), 7=100 \%$ ethanolic extract $(10.24 \mu \mathrm{g} / \mathrm{spot})$.

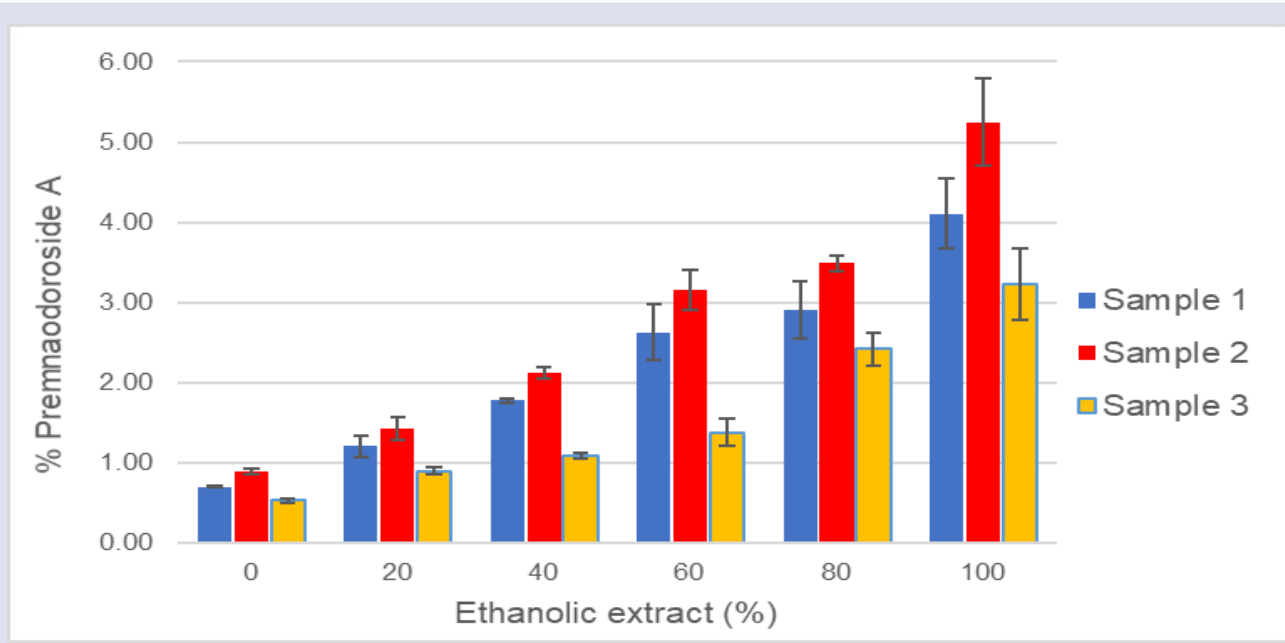

Figure 3: The content of premnaodoroside $A$ in the extracts. 

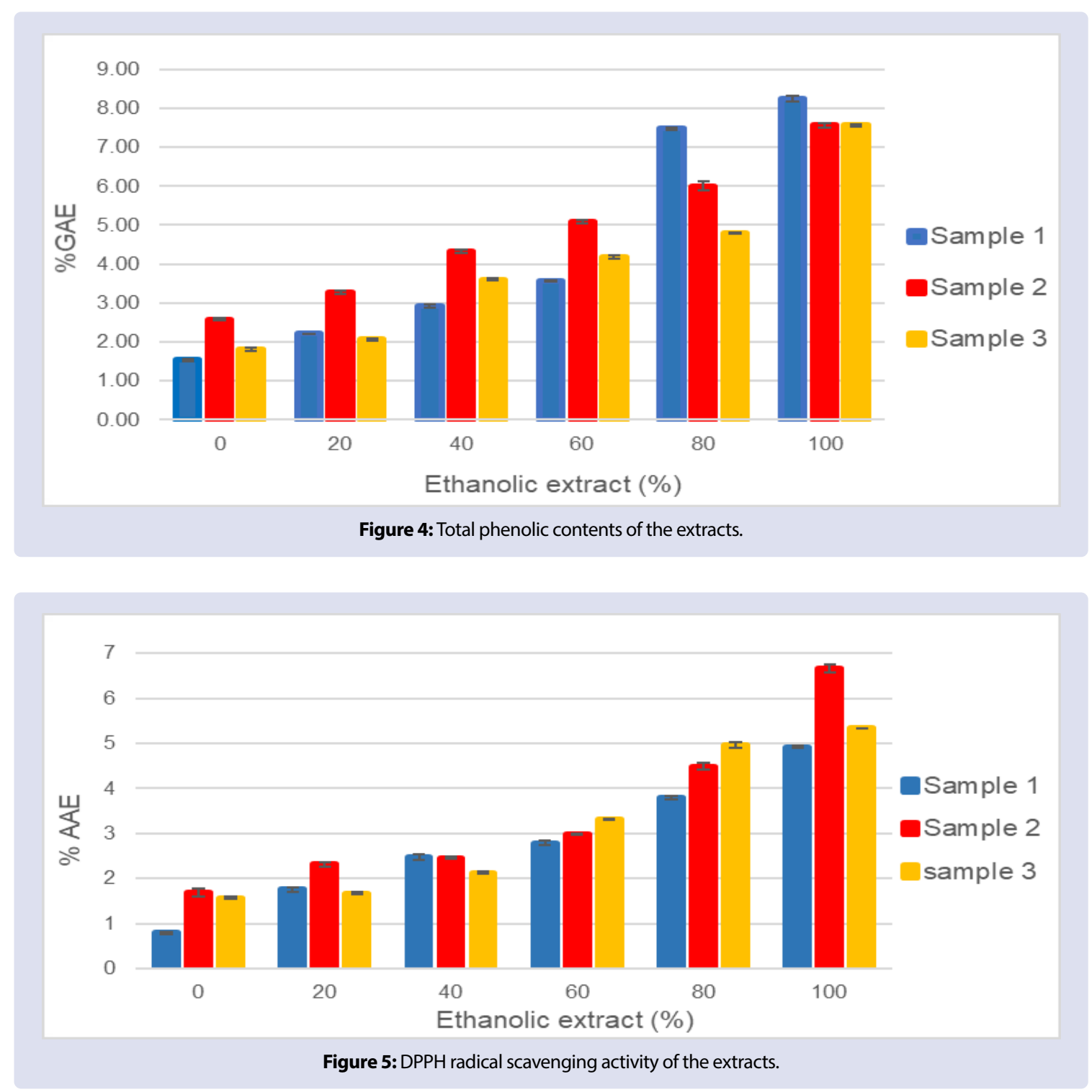

\section{DISCUSSION}

Several factors affect the quality of herbal extract. This research studied the effects of $\%$ of ethanol solvent on the yield, the contents of premnaodoroside A and total phenolic compounds, and antioxidant activity of the resulting extracts of the leaves of $P$. serratifolia. premnaodoroside A was the major iridoid glycoside. It has been reported from this plant ${ }^{7}$ and other Premna species, such as P. integrifolia ${ }^{7}$ and P. odorata. ${ }^{16}$ Iridoid glycosides possessed several bioactivities, such as antibacterial, antioxidant, cytotoxic, neuroprotective and hepatoprotective activities. ${ }^{18}$ Besides premnaodoroside A, several phenolic compounds have been reported from the leaves of this plant, for examples, $p$-anisaldehyde, methyl salicylate, $p$-vinyl anisole, acacetin, acacetin-7-O-glycoside, quercetin, kaempferol, and luteolin. ${ }^{19,20}$ Phenolic compounds usually related to antioxidative activity and have therapeutic effects of inflammation, oxidative stress and other metabolic diseases. ${ }^{21}$ The leaves of this plant also have been ever reported antioxidant activity. Therefore, in this experiment, the contents of premnaodoroside $\mathrm{A}$, the total phenolics and the antioxidants were considered as the quality markers of the extracts.

A TLC-densitometric method was developed to determine the contents of premnaodoroside A. This method has been generally used for the quantitation of iridoids in several previous publications. ${ }^{22-24}$ It used less chemicals, low cost, short time analysis and eco-friendly. ${ }^{23}$ After validation in compliance with ICH guideline, the method was reliable and suitable for the quantitation of premnaodoroside A. However, the color of the compound on TLC faded with time after derivatization and it should be much concerned. Therefore, TLC scanning after derivatization for 15 minutes was fixed for all experiments.

The contents of premnaodoroside A, the total phenolic compounds and the antioxidants of the samples collected from three different sources were varied but were in the same tendency. The contents of all compounds in $0 \%$ ethanol extract were the lowest and increased with increasing \% of ethanol solvent. This result suggested that solubility of these compounds in ethanol was better than in water. This finding contradicted the traditional preparing method of infusion and decoction in water for antidiabetic food and drink additive. ${ }^{11}$ However, some investigators described that the infusion and the decoction of P. serratifolia leaves have antidiabetic and antioxidant activity, ${ }^{11}$ and could be consumed as a food and drink additive for antidiabetic agent. The leaves of $P$. serratifolia might contain several highly inert polar substances, such as protein, pectin, mucilage and inorganic salts, which dissolved in water and diluted the content of the interesting markers of this study. The infusion and the decoction might give medicinal preparations with a gentle potency, and they were convenient according to the traditional style. To develop high quality extracts, the 


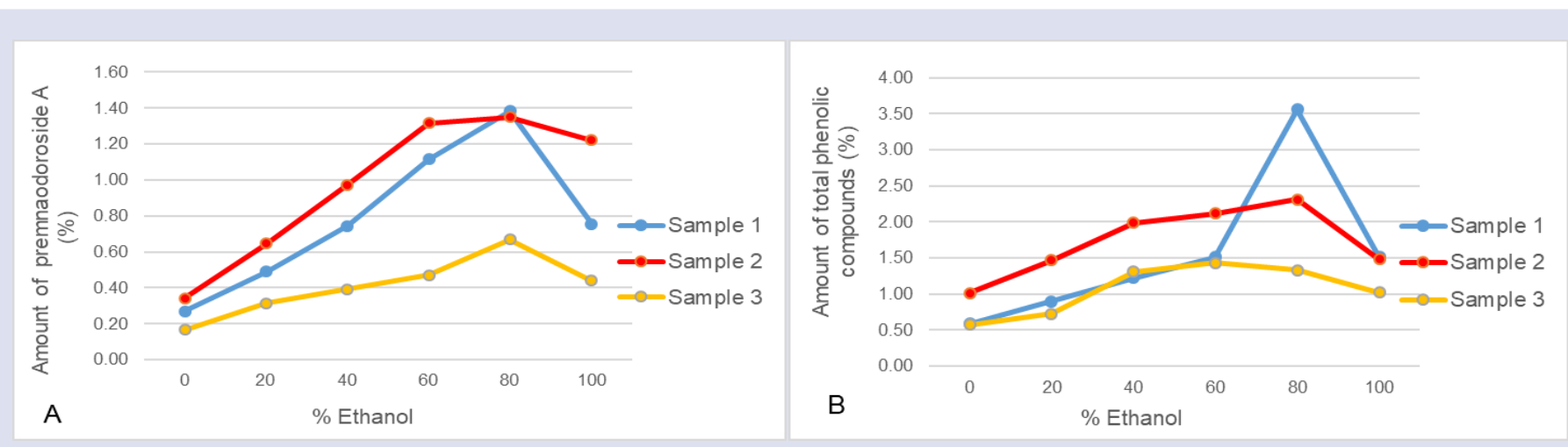
using various \%of ethanol as extraction solvent.

results of this study indicated that the concentration of the interesting compounds in $100 \%$ ethanolic extract was the highest. However, comparing with other extracts, it gave the lowest yield (Table 1). Its yield was 2.5 times lower than that of the highest yield of $80 \%$ ethanolic extract of sample 1, and $40 \%$ ethanol extracts of samples 2 and 3 . Quality and quantity should be considered together for the production of herbal extract. To optimize the percentage of the using ethanol solvent, the extractive amounts of premnaodoroside $\mathrm{A}$, the total phenolic compounds and the antioxidants from plant material were calculated from yields of the extracts and their contents of these compounds. The result obtained from each \% ethanol is shown in Figure 6.

The results of all samples were in the same manner. The $80 \%$ ethanol could extract the highest amounts of all compounds, except for sample 3, where the highest amounts of the phenolic compounds were obtained from $60 \%$ ethanol (but not much different from $80 \%$ ). Then $80 \%$ ethanol was considered to possess the highest extractive power for the extraction of these bioactive compounds from $P$. serratifolia leaves. However, the concentrations of these compounds were diluted with other constituents which were also extracted with $80 \%$ ethanol. Even the quality of the $80 \%$ ethanol extract was lower than the $100 \%$ ethanol extract, but it could be compensated by the higher extractive yield. In practice, more extractive yield could produce a greater number of medicinal dosages. The $80 \%$ ethanol extract gave a higher extractive yield, but less concentrations of the bioactive compounds. So, it required a higher dose to obtain the equivalent potency of the $100 \%$ ethanolic extract. 100\% Ethanol extract showed higher concentrations of all interesting compounds which might be convenient in practice for medicinal administration at a lower dose with high potency, but its productivity was limited by the low extractive yield.

\section{CONCLUSION}

This study reported that the percentage concentration of ethanol solvent had significant effects on the contents of an iridoid glycoside (premnaodoroside A), the total phenolics and the antioxidants of the
P. serratifolia leaf extracts. In addition, a TLC-densitometric method was developed for the quantitation analysis of premnaodoroside $\mathrm{A}$. The $100 \%$ ethanol extracts possessed the highest contents of all interesting compounds, vice versa, theirs extractive yields were the lowest. Considering on the quantitative assessment, the $80 \%$ ethanol was more advantageous. These pros and cons had to be weighed depending on further application of the extracts.

\section{ACKNOWLEDGEMENTS}

We would like to express our gratitude to the Faculty of Pharmacy, Silpakorn University, Thailand to provide the chemicals, glassware, equipment and laboratory support that were used in this study.

\section{REFERENCES}

1. Chua I, King P, Ong KH, Sarbini SR, Yiu PH. Influence of light intensity and temperature on antioxidant activity in Premna serratifolia L. J Soil Sci Plant Nutr. 2015;15(3):605-14.

2. Vadivu R, Suresh AJ, Girinath K, Kannan PB, Vimala R, Kumar NS Evaluation of hepatoprotective and in-vitro cytotoxic activity of leaves of Premna serratifolia Linn. J Sci Res. 2009;1(1):145-52.

3. Biradi M, Hullatti K. Bioactivity guided isolation of cytotoxic terpenoids and steroids from Premna serratifolia. Pharm Biol. 2017;55(1):1375-9.

4. Minh NP. Different factors affecting dried herbal tea production from Premna serratifolia leaf. J Pharm Sci Res. 2019;11(3):806-8.

5. Uppin JB, Naik GR. Evaluation of phytochemical and antimicrobial activity of Premna integrifolia leaf extract. European J Biotechnol Biosci. 2017:5(5):17-9.

6. Hang NTB, Ky PT, Van Minh C, Cuong NX, Thao NP, Van Kiem P. Study on the chemical constituents of Premna integrifolia $L$. Nat Prod Commun. 2008;3(9):1449-52.

7. Hang NTB, Ky PT, Van Minh C, Thao NP, Van Kiem P. Premnaodoroside $A$ and $10-O$-trans-p-methoxycinnamoylcatalpol, two iridoid glycoside derivatives from the leaves of Premna integrifolia L. Vietnam J Chem. 2009;47(2):230-5. 
8. Crişan G, Vlase L, Balica G, Muntean D, Ştefănescu C, Păltinean R, et al. LC/MS analysis of aucubin and catalpol of some Veronica species. Farm. 2010;58(2):237-42

9. Sertić M, Crkvenčić M, Mornar A, Pilepić KH, Nigović B, Maleš Ž. Analysis of aucubin and catalpol content in different plant parts of four Globularia species. J Appl Bot Food Qual. 2015;88(1):209-14.

10. Yadav AK, Tiwari N, Srivastava P, Singh SC, Shanker K, Verma RK et al. Iridoid glycoside-based quantitative chromatographic fingerprint analysis: A rational approach for quality assessment of Indian medicinal plant Gambhari (Gmelina arborea). J Pharm Biomed Anal. 2008;47(4-5):841-6.

11. Yee KS, Wetwitayaklung $P$, Narakornwit $W$, Sukwattanasinit $T$, Wangwattana B, Sotanaphun U. Variation in chemical constituents of essential oils of the fresh, dried and fermented leaves of Premna serratifolia. Pharm Sci Asia. 2021;48(5):482-91.

12. Timotius KH, Simamora A, Santoso AW. Chemical characteristics and in vitro antidiabetic and antioxidant activities of Premna serratifolia L. leaf infusion and decoction. Pharmacog J. 2018;10(6):1114-8.

13. World Health Organization. WHO expert committee on specifications for pharmaceutical preparations, fifty-second report. Geneva: WHO Press, p. 103-4; 2018

14. Shou-liang C, Gilbert MG. Verbenaceae. In: Wu Z, Raven PH, editors. Flora of China, Volume17: Verbenaceae through Solanaceae. St.Louis: Missouri Botanical Garden Press; 1994. p. 1-49.

15. Leeratiwong $C$, Chantaranothai $P$, Paton AJ. A synopsis of the genus Premna L. (Lamiaceae) in Thailand. Trop Nat Hist. 2009:9(2):113-42.

16. Otsuka H, Kashima N, Hayashi T, Kubo N, Yamasaki K, Padolina WG Premnaodorosides A, B and C, iridoid glucoside diesters of an acyclic monoterpenediol from leaves of Premna odorata. Phytochemistry. 1992;31(90):3129-33.
17. ICH-Q2 (R1) 2005. Validation of Analytical Procedures: Text and Methodology. International Conference on Harmonization: Geneva.

18. Zhang J, Ip FC, Liang Y, Ip NY, Zhong B-L, Lai C-W, et al. A new iridoid glycoside and a new cinnamoyl glycoside from Scrophularia ningpoensis Hemsl. Nat Prod Res. 2017;31(20):2361-8.

19. Salih GA, Ahmad-Raus R, Shaban M, Abdullah N. Extraction and purification of cytotoxic compounds from Premna serratifolia L. (Bebuas) for human breast cancer treatment. Int Food Res J. 2017:24:281-6.

20. Singh C, Prakash C, Tiwari KN, Mishra SK, Kumar V. Premna integrifolia ameliorates cyclophosphamide-induced hepatotoxicity by modulation of oxidative stress and apoptosis. Biomed Pharmacother. 2018;107:634-43.

21. Choi HJ, Park DH, Song SH, Yoon IS, Cho SS. Development and validation of a HPLC-UV method for extraction optimization and biological evaluation of hot-water and ethanolic extracts of Dendropanax morbifera leaves. Molecules. 2018;23(3):1-11.

22. Hajimehdipoor H, Shekarchi M, PiraliHamedani M, Abedi Z, Zahedi $\mathrm{H}$, Shekarchi M, et al. A validated HPTLC-densitometric method for assay of aucubin in Vitexagnus-castus L. Iran J Pharm Sci. 2011;10(4):705-10

23. Yadav D, Gupta M. Isolation and HPTLC analysis of iridoids in Premna integrifolia, an important ingredient of ayurvedic drug Dashmool. JPC-J Planar Chromat. 2013;26(3):260-6.

24. Krzek J, Janeczko Z, Walusiak D, Podolak I. Densitometric determination of aucubin in syrups in the presence of other iridoids-An approach to standardization. JPC-J Planar Chromat. 2002;15(3):196-9.

\section{GRAPHICAL ABSTRACT}

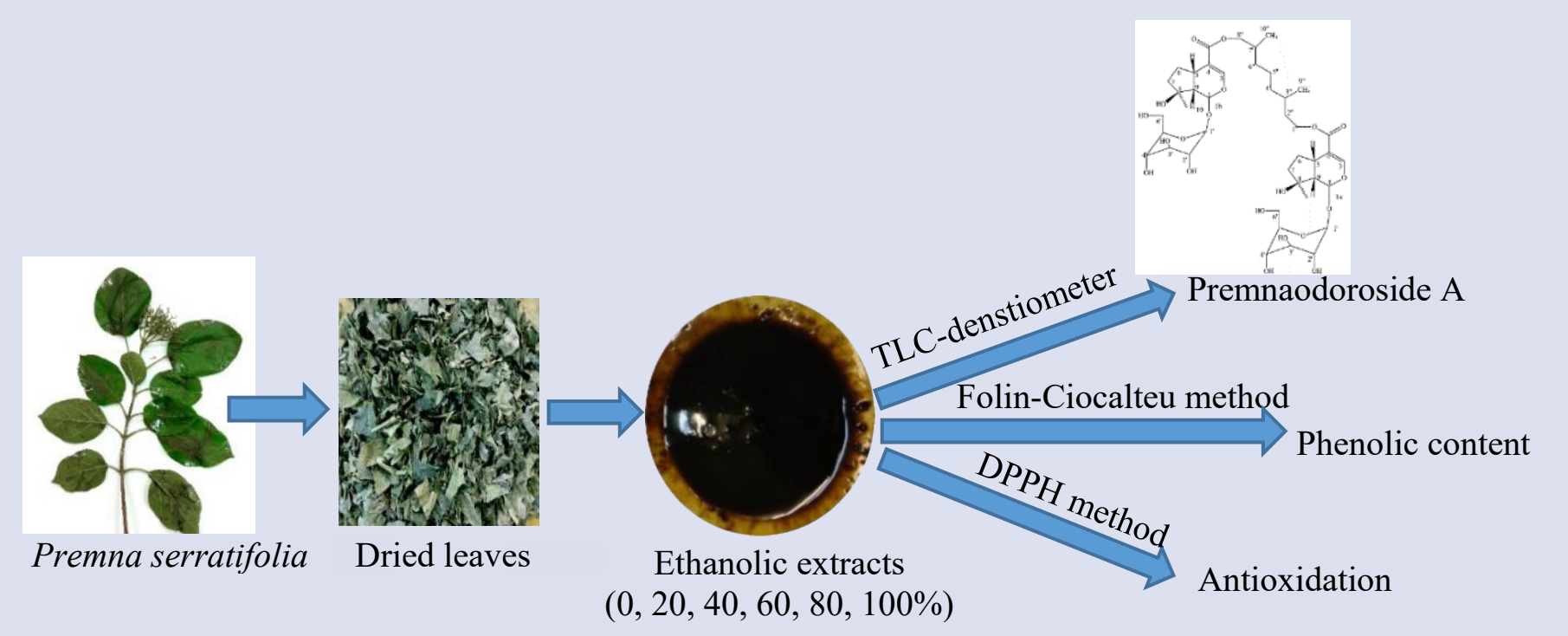




\section{ABOUT AUTHORS}
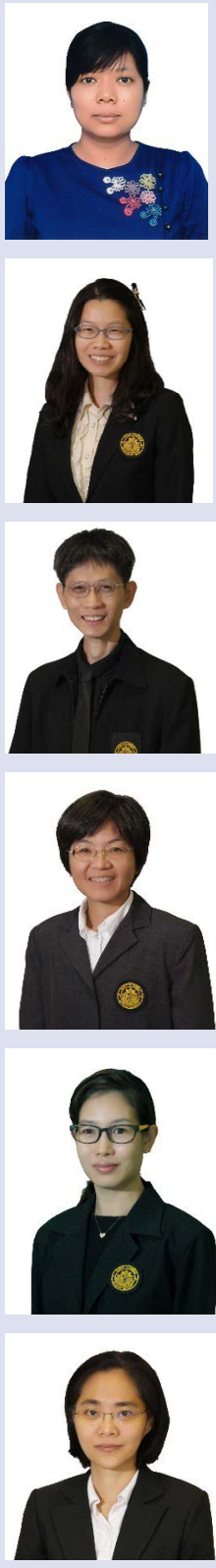

Khin Su Yee has been a Lecturer in the Department of Pharmacognosy, University of Pharmacy, Mandalay, Myanmar. Now she is studying the Doctoral degree in Pharmaceutical Sciences from Silpakorn University.

Tasamaporn Sukwattanasinit works as lecturer in the Department of Pharmacognosy, Faculty of Pharmacy, Silpakorn University, Thailand. She earned a doctoral degree in Pharmaceutical Chemistry and Natural Products from Silpakorn University. Her interested fields are phytochemistry and quality control of herbal medicines and natural products.

Uthai Sotanaphun is a lecturer in Department of Pharmacognosy, Faculty of Pharmacy, Silpakorn University, Thailand. He received his doctoral degree in Pharmaceutical Chemistry and Natural Products from Chulalongkorn University, Thailand. His interested fields are pharmacognosy and quality control of herbal medicines.

Penpun Wetwitayaklung works in Department of Pharmacognosy, Faculty of Pharmacy, Silpakorn University, Sanamchand Palace Campus, Nakhon Pathom, Thailand, 73000. She received her doctoral degree in Pharmaceutical chemistry. Her interested fields are phytochemistry and quality control of herbal medicines and natural products.

Bunyapa Wangwattana received her bachelor degree in Pharmacy, master's degree in Pharmacy (Pharmacognosy) from Mahidol University, Thailand; and her Ph.D. in Pharmaceutical Science from Chiba University, Japan. Now, she is an Assistant Professor in Department of Pharmacognosy, Silpakorn University, Thailand. Her research interests include phytochemistry and pharmacognosy.

Worrakanya Narakornwit works in Department of Pharmacognosy, Faculty of Pharmacy, Silpakorn University, Sanamchand Palace Campus, Nakhon Pathom, Thailand, 73000. Doctoral degree in Pharmaceutical Chemistry and Natural Products from Chulalongkorn University. Her interested fields are phytochemistry and quality control of herbal medicines and natural products.

Cite this article: Yee KS, Sukwattanasinit T, Sotanaphun U, Wetwitayaklung P, Wangwattana B, Narakornwit W. Optimization of Solvent Extraction of the Leaves of Premna serratifolia and Quantitation of Premnaodoroside A by Validated TLC-densitometric Method. Pharmacogn J. 2021;13(6)Suppl: 1656-1663. 